University of Nebraska - Lincoln

DigitalCommons@University of Nebraska - Lincoln

French Language and Literature Papers

Modern Languages and Literatures, Department

2021

\title{
Quatre photos
}

Lydie Salvayre

Follow this and additional works at: https://digitalcommons.unl.edu/modlangfrench

Part of the French and Francophone Language and Literature Commons

This Article is brought to you for free and open access by the Modern Languages and Literatures, Department of at DigitalCommons@University of Nebraska - Lincoln. It has been accepted for inclusion in French Language and Literature Papers by an authorized administrator of DigitalCommons@University of Nebraska - Lincoln. 


\section{Lydie Salvayre}

\section{Quatre photos}

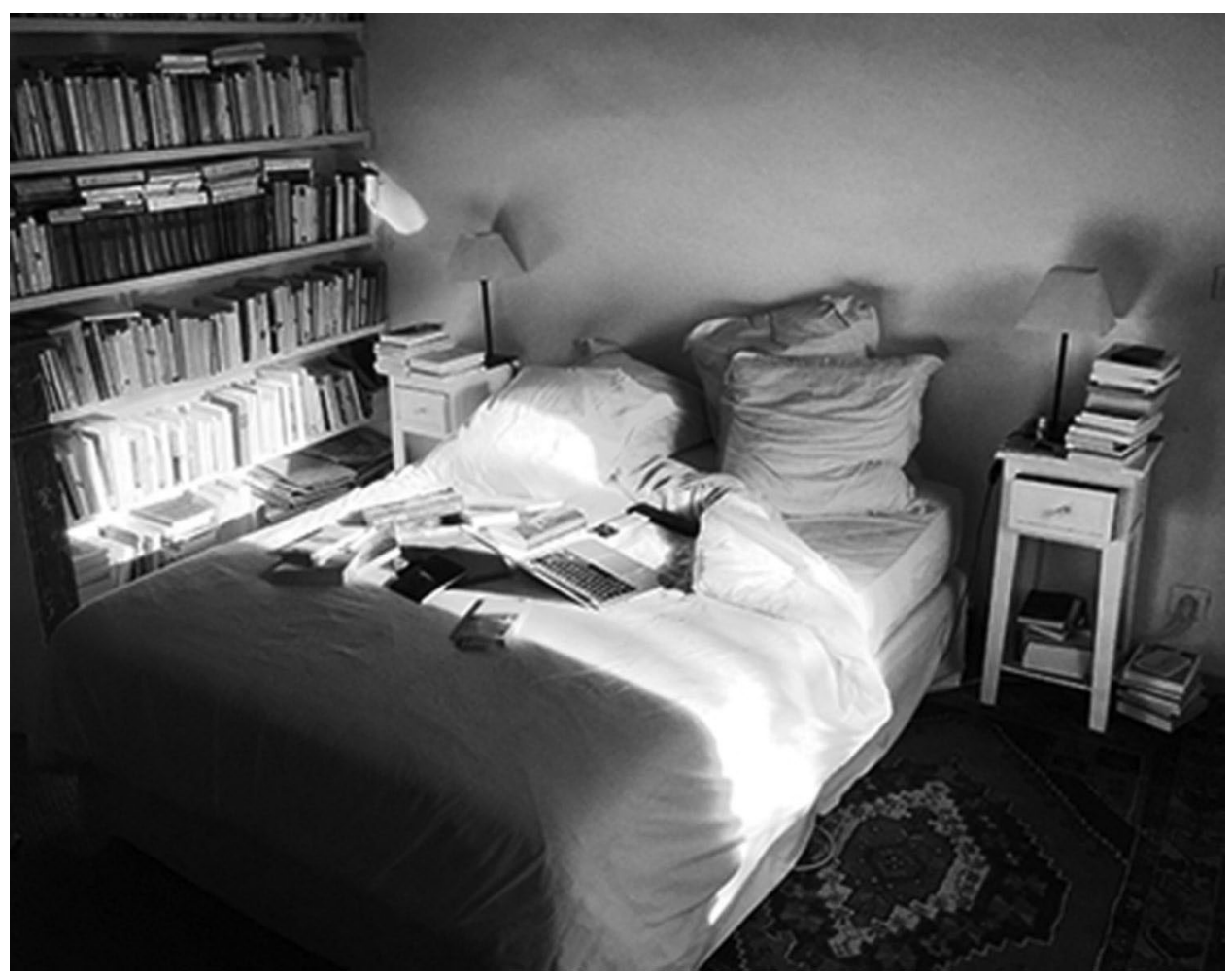

«Au fond je suis un sportif, le sportif au lit. »

- Henri Michaux

Published in Lydie Salvayre, maintenant même, ed. Warren Motte (Lincoln, NE : Zea Books, 2021). doi: 10.32873/unl.dc.zea.1285 
QUATRE PHOTOS

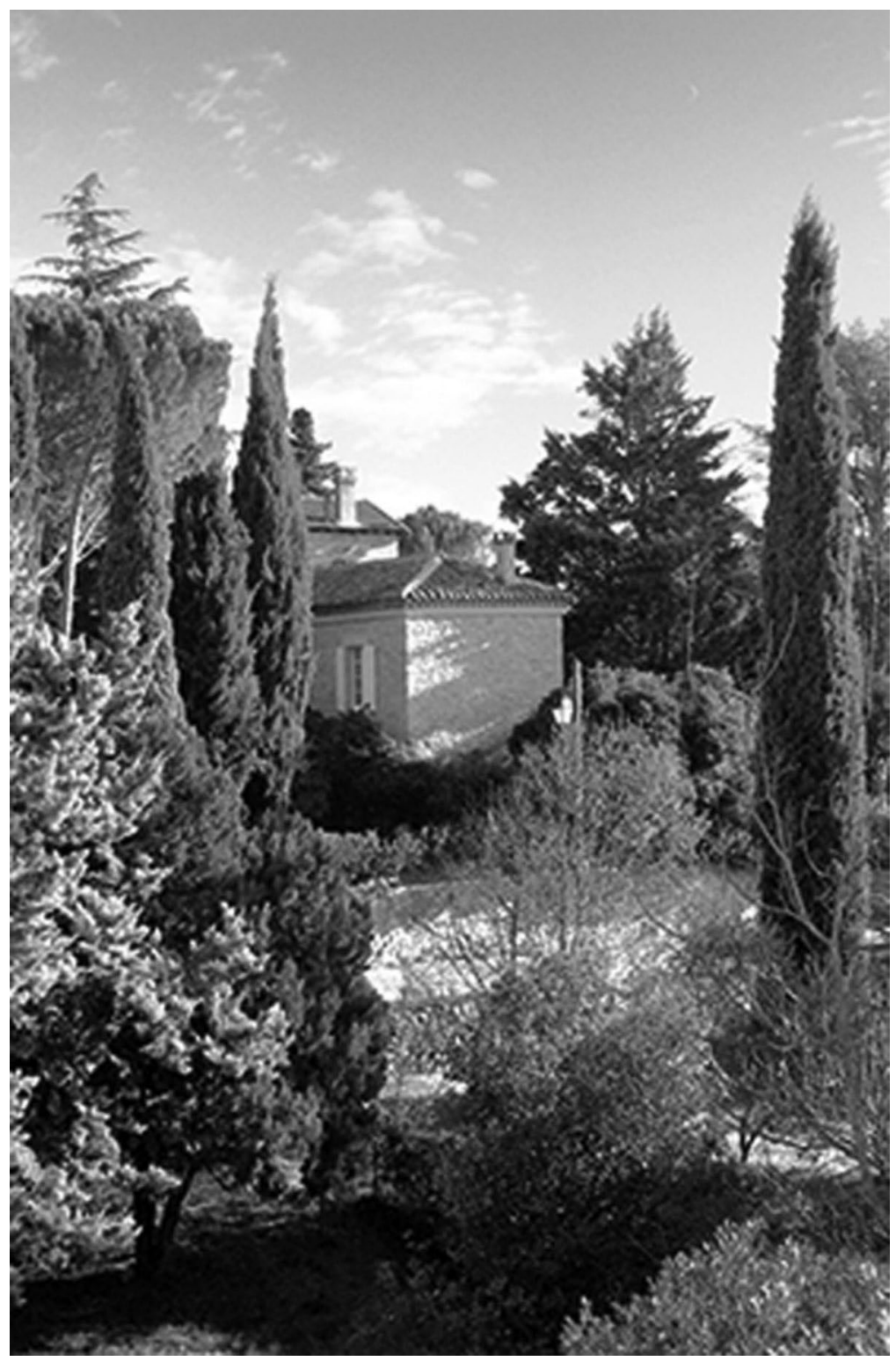

Chambre avec vue 
LYDIE SALVAYRE

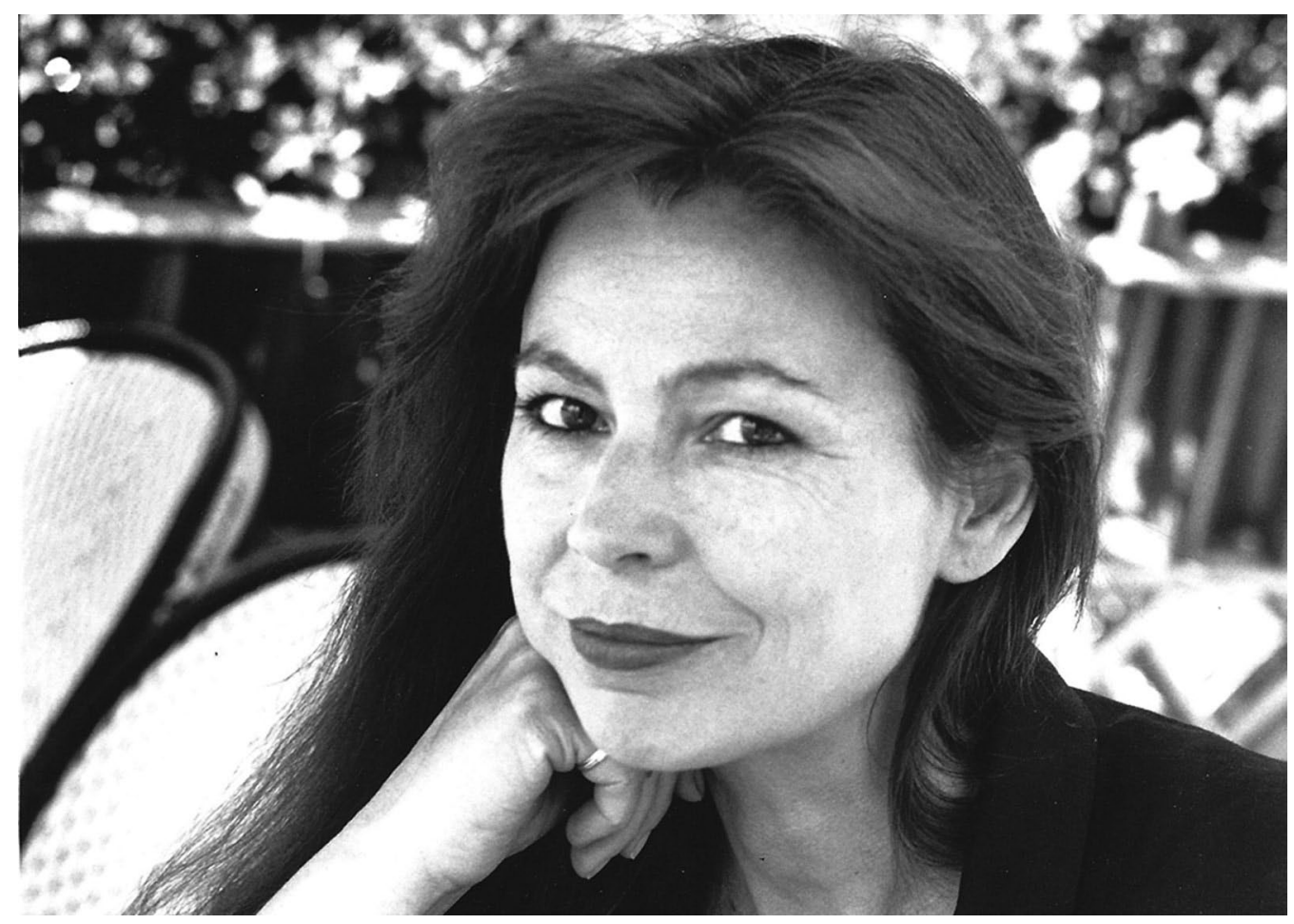

Lydie Salvayre - Paris - Mai 2013 
QUATRE PHOTOS

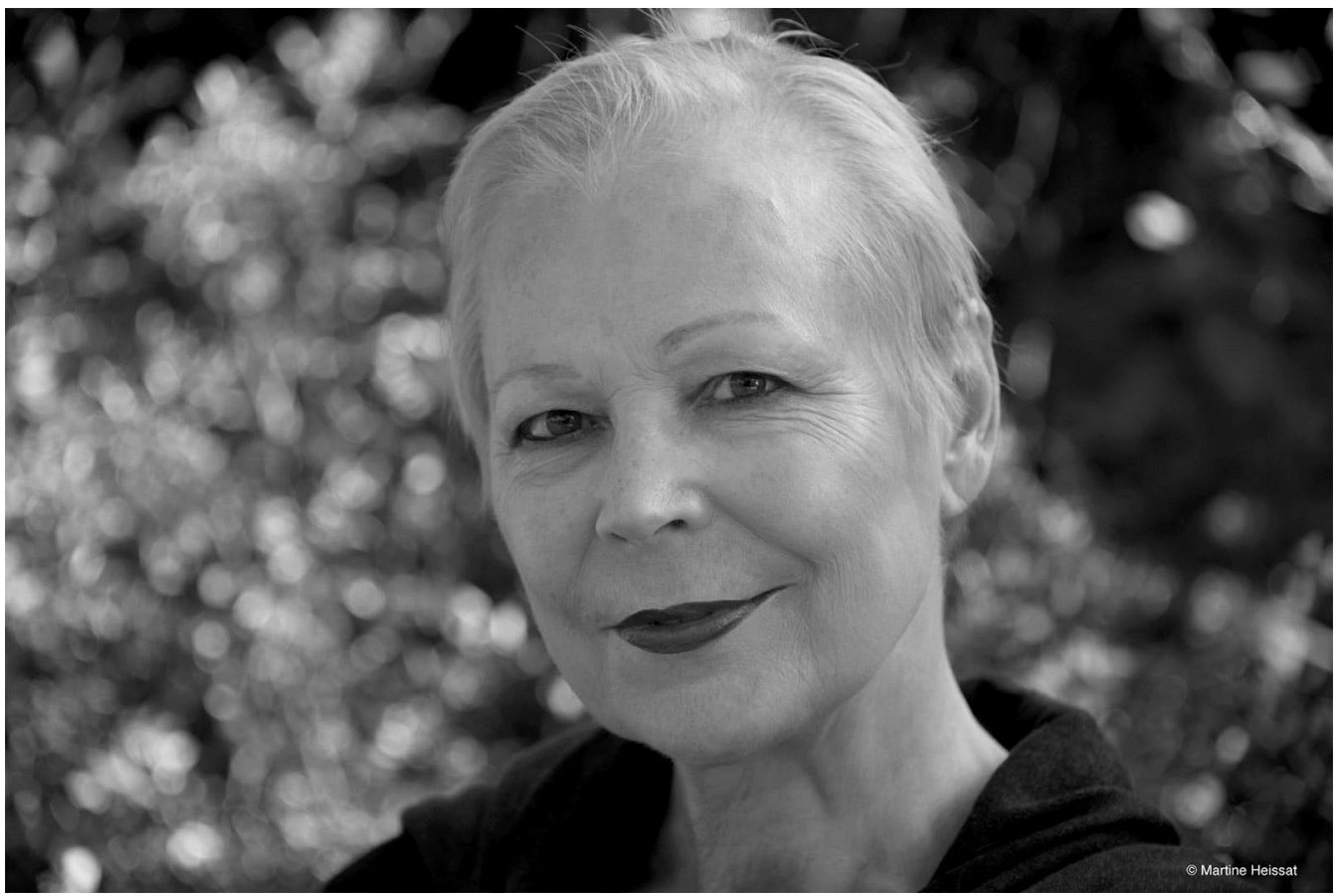

Lydie Salvayre - Le Pin - Juin 2018 